\title{
Managing Climate Change Risks in Food Systems
}

\subsection{INTRODUCTION}

Through this book, we have presented arguments for developing a robust and equitable food system which is anchored on the goal that all individuals who depend on it have to be able to secure food and nutrition for greater welfare. Food and nutrition security in its broadest definition refers to the ability of individuals to access good quality, nutritious foods that are affordable and available at all times. In addition to providing access to nutritious foods, food systems have to account for external conditions, such as vagaries of the weather, and political stability, which moderate the ability of individuals to access nutrition. In this context, climate change has been identified as one of the greatest threats to food and nutrition security. This complex phenomenon, which involves changing weather patterns, increased incidence of extreme weather events and the reduction in the quality of natural resources, is expected to impact food systems through multiple channels. One, by changing optimal growing conditions for crops and increasing uncertainty in extreme weather events, climate change is expected to impact the availability of food and nutrients. Two, at the current level of technology, climate change will increase uncertainty in production. This can lower access to nutrients and nutrition in the food that is already available for consumption. In combination with its effects on overall health quality of individuals, climate change will reduce the ability of individuals to absorb nutrients,

(C) The Author(s) 2019

P. Pingali et al., Transforming Food Systems for a Rising India, Palgrave Studies in Agricultural Economics and Food Policy, https://doi.org/10.1007/978-3-030-14409-8_10 
thus impacting labor productivity. This, in turn, would reduce future economic growth prospects. Finally, climate change is expected to negatively impact economic development by increasing the vulnerability of different regions and different population groups. For example, for those with social disadvantages, lower ability to cope with climate changes will further increase their risk of hunger and food insecurity. Similarly, regions with low rural development and high poverty rates will be less capable of adapting to climate change.

In this chapter, we review climate change related risks on food systems. We outline the various pathways through which climate change impacts food systems and emphasize evidence from India. We discuss policy and institutional measures that are currently in place to mitigate and manage these risks. Keeping in sight the food security needs of the future, we also discuss some guiding principles for mitigation and adaptation strategies that can be included in these policies that can help in creating robust food systems.

\subsection{What Is India's Experience of Climate Change Thus Far?}

At its core, climate change refers to the fallout of the phenomenon of increasing global temperatures, due to increased greenhouse gas (GHG) emissions, ${ }^{1}$ on human welfare. Increase in global temperature has been associated with the melting of glaciers, changing intensity of precipitation cycles, melting of permafrost in the arctic, depletion of the ozone layers and the acidification of oceans (Cruz et al., 2007; IPCC, 2014; Schuur et al., 2015; Shrestha, Gautam, \& Bawa, 2012; Speers, Besedin, Palardy, \& Moore, 2016). Extreme events such as high-intensity hurricanes,

\footnotetext{
${ }^{1}$ GHG contributes to warming of temperatures by their ability to absorb and emit radiant energy from thermal infrared radiations. The primary GHGs in the earth's atmosphere are carbon dioxide $\left(\mathrm{CO}_{2}\right)$, ozone, nitrous oxide methane and water vapor. Human activity in the post-industrial era is the prime contributor to $\mathrm{CO}_{2}$ increasing from $280 \mathrm{ppm}$ in the early 1800 s to around $400 \mathrm{ppm}$ in 2014 (ppm-parts per million). This is a $40 \%$ increase over the 250 years, the highest ever in the paleo experience of the earth. Nearly $80 \%$ of these $\mathrm{CO}_{2}$ emissions come from industrial processes and the burning of fossil fuels while the rest of the $20 \%$ comes from deforestation, land clearing and degradation of soils. Increase in global GHG emissions have increased average global temperatures by around 1 degree Celsius (IPCC, 2014).
} 
flooding, droughts, forest fires, extreme heating of lakes, changing coastlines and so on are perceivable and measureable outcomes of climate change. These have been increasing in both frequency and intensity over the last decade, and the distress caused to human health, economic development and agricultural systems has been well documented across the globe (IPCC, 2014).

Experts have also brought to the fore the more immediate impacts of global warming in the Indian subcontinent. In the last 50 years, satellite data suggest that maximum temperature increases have been around 1 degree Celsius across the country (Fig. 10.1). Current projections estimate further increases by around 2 to 4 degree Celsius by the end of the century. Also, projections also show regional variation in the impacts of temperature. For example, the western and the southern parts of the country are expected to see the greatest increases with regard to temperature. Increase in the mean temperature and increases in the number of hot days have been documented across the country as well (IMD, 2018; K. R. Kumar, Kumar, \& Pant, 1994). Changes in precipitation patterns such as increased floods, increased incidences of severe droughts, changing optimal growing seasons and changes in rainy period start dates have created already increased
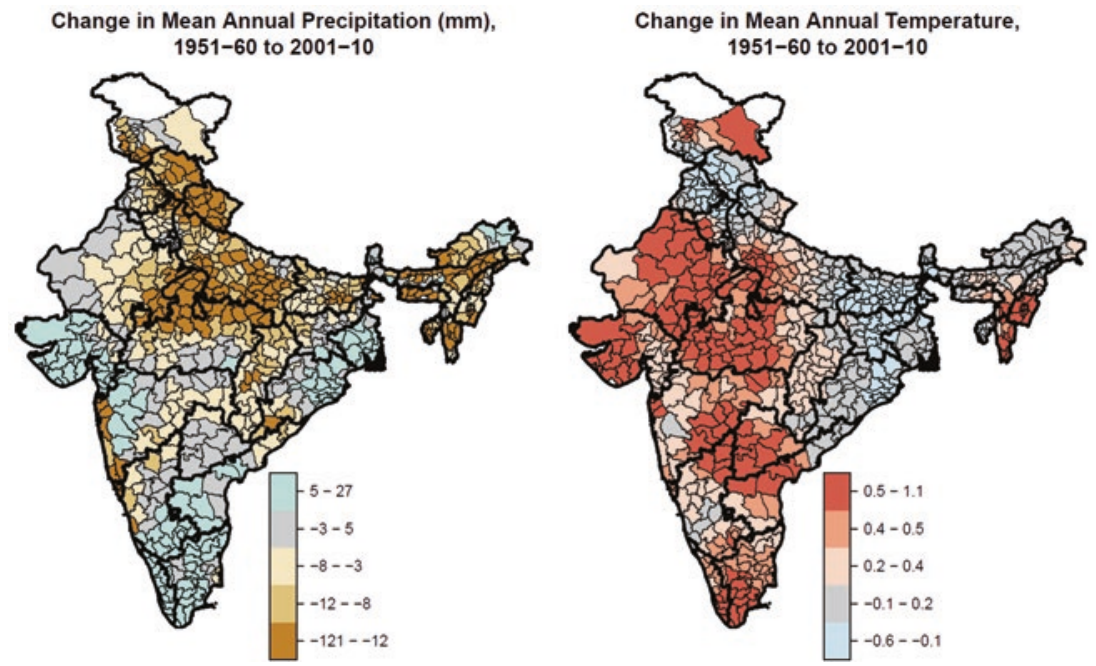

Fig. 10.1 Temperature (degree Celsius) and rainfall $(\mathrm{mm})$ change. Source: AidGeo Data; based on authors calculations 
uncertainty for agricultural systems (Kothawale \& Rupa Kumar, 2005; K. S. K. Kumar \& Parikh, 2001; S. N. Kumar, Yadav, Jee, Kumar, \& Chauhan, 2011; A. K. Misra, 2014; O'Brien et al., 2004; A. Sharma \& Pingali, 2016). Figure 10.1 also shows us some of these significant changes in the rainfall pattern across the country. ${ }^{2}$ Here we see that parts of the north and northwest have seen a decline in precipitation while southern, eastern and northeastern regions have seen an increase in precipitation over time. There is also evidence that increase in the rate of glaciers melting in the Himalayas has increased downstream flooding thus impacting the productivity of lowlands (Kattelmann, 2003; Shrestha et al., 2012; Vedwan \& Rhoades, 2001; Watanabe, Ives, \& Hammond, 1994). Excessive deforestation and indiscriminate land clearing have also contributed to flooding and have increased air pollution (Sinha \& Swaminathan, 1992; E. Somanathan, Prabhakar, \& Mehta, 2009). Increased traffic, urban congestion, poor waste management and land degradation have also been linked with increasing pollution and higher carbon emission rates across the country's landscape (Auffhammer, Ramanathan, \& Vincent, 2006; J. Burney \& Ramanathan, 2014; R. Gupta, Somanathan, \& Dey, 2017; O'Brien et al., 2004). Even in current folklore, the urban rich complain about buying new air conditioners since summers have become too hot and also complain that pollution prevents them from enjoying the cool winter breeze. In rural areas, farmers now concede that they can no longer accurately predict changing rainfall patterns and intensity and their ground water sources are drying up. These anecdotal conversations find themselves validated in journalistic articles that further reinforce the importance of both accepting and also addressing the problem that climate change poses to us as a population. However, aside from these directly perceived changes to welfare, climate change creates additional challenges to food systems as we look ahead.

\subsection{Pathways Through Which Climate Changes IMPACT FOOD SYSTEMS}

By increasing the probability and frequency of extreme weather events, climate change can impact food systems in the following ways (Fig. 10.2). First, by reducing access to water, ${ }^{3}$ increasing unpredictability of weather

\footnotetext{
${ }^{2}$ In the paper by (Mall et al., 2006), authors show evidence that changes to temperature and rainfall will become evident by 2040 in India.

${ }^{3}$ In Chap. 8, we discussed the problem of lack of water access in more detail. Hence we do not delve further into the topic in this chapter.
} 


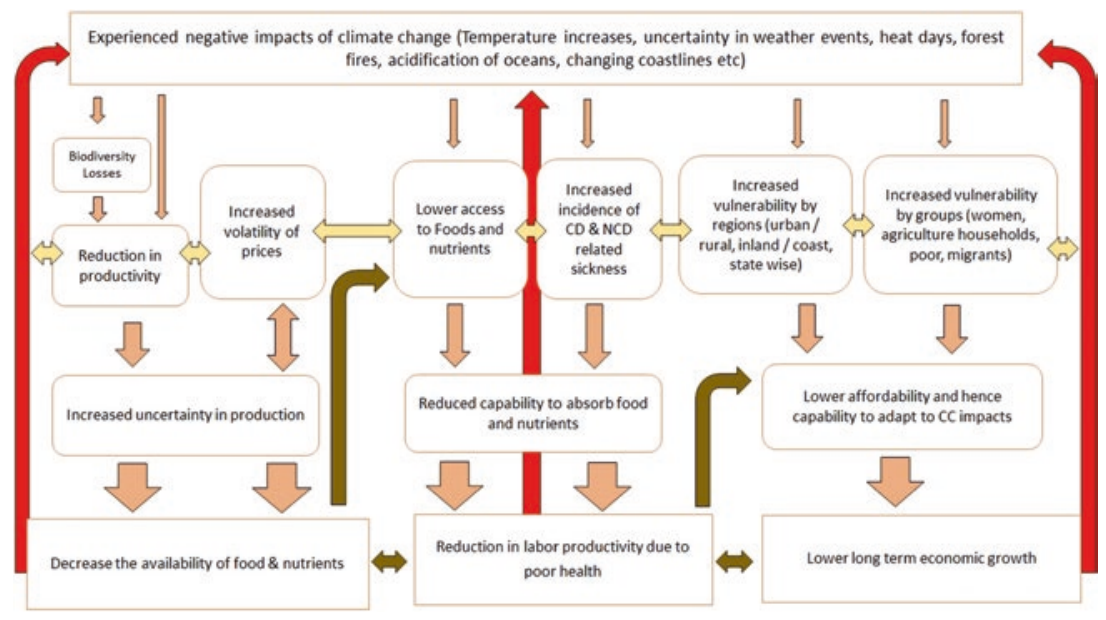

Fig. 10.2 Pathways: Impact of climate change on food systems

conditions and reducing the quality of natural resources on which crops depend, climate change can increase uncertainty with regard to food production. This, in turn, can reduce food and nutrition availability and increase food price volatility. Two, climate change can reduce labor productivity by affecting individual's health both directly and indirectly. By increasing morbidity and the severity of communicable and non-communicable diseases, climate change can reduce an individual's capability to absorb nutrients from food, thus reducing health. Through the channel of increased volatility of food prices and decreased food and nutrient availability, climate change reduces access to food. This too impacts the health of individuals and hence their labor productivity. In the absence of safety nets, lower labor productivity reduces the affordability of individuals and hence reduces their economic growth prospects for the future. Finally, climate change can directly reduce economic opportunities by increasing the vulnerability of certain regions and population groups. Vulnerable groups such as people living in coastal areas, poor rural agricultural households and women and older individuals may experience the negative effects of climate change by more if they do not have the appropriate capabilities to adapt to its negative effects. This, in turn, lowers long-term economic growth prospects for both individuals and food systems. Decrease in food availability, labor productivity and lower long-term economic growth may 
create a vicious cycle of low adaptation capability towards climate change which can worsen its impacts on individuals. In the next section, we present evidence on these pathways and we bring forth evidence from India on the same.

\subsubsection{Impacts on Food and Nutrient Availability}

Climate change impacts food and nutrient availability by reducing agricultural productivity both directly and indirectly. In the absence of crop technologies to tide over the vagaries of weather, climate change can increase production uncertainty as well as decrease crop and livestock productivity. With lower amounts of foods available, climate change can directly impact total nutrient availability within a food system. Climate change can also impact the quality of natural resources on which human food production depends. Soil degradation and acidification of oceans can reduce the quality of nutrients by impacting the health of crops, livestock and fisheries. Finally, an indirect method through which climate change can impact food and nutrient availability is through increasing price volatility. As food and nutrient availability decreases and extreme events threaten their production, increasing prices and increased price volatility will reduce access if income increases cannot keep pace with these changes. Also, if actors along the food supply chain do not store food properly or distribute surpluses across times of shortages, this can further reduce the availability of foods and nutrients for individuals. In this section, we highlight some of the research on this pathway.

\subsubsection{Impact on Agricultural Productivity}

Plant scientists agree that quantifying the impact of increasing temperatures on crop yield is not straightforward. For example, temperature increases have been found to have beneficial impacts if it combined with other optimal growing conditions. Increase in atmospheric $\mathrm{CO}_{2}$ (a GHG) too, can improve crop growth performance by increasing the rate of photosynthesis and water use efficiency (Challinor et al., 2014; Lobell \& Burke, 2010; Nelson, Mensbrugghe et al., 2014). However, there few important caveats that need to hold for the conclusion that yield changes can be positive. One, agricultural systems require adequate ground water management systems and enough access to irrigation to tide over changes in precipitation patterns that come with climate change (A. K. Misra, 2014; Qadir et al., 2008; R. G. Taylor et al., 2013). Two, temperature need to 
remain increase below 30 degree Celsius during the growing season. After this threshold, temperature increases are considered to be extremely damaging to yields for crops that are rain fed (IPCC, 2014). Even across crop groups, total impacts on yields are found to differ. For example, climate model projections find that with adequate irrigation, rice crops may actually benefit but crops such as wheat and maize will lose out (Challinor et al., 2014; Nelson, Mensbrugghe et al., 2014). Also, much of the research on the impacts of climate has been conducted in developed countries, which are located in temperature zones where increases in temperature will be beneficial. However, many developing and emerging countries are in tropical zones. Due to their geographical locations, these areas are expecting to see an unfavorable increase in temperature which has greater impacts on food production and hence food security. Three, scientists have also established that even if there may be net benefits to calorie availability through greater yields, a major fallout of climate change will be lower bioavailability of protein and micronutrients such as iron and zinc which are more sensitive to changes in plant physiology due to climate change (Dietterich et al., 2014; Müller, Elliott, \& Levermann, 2014).

In India too, projections of climate impact on yields and production have shown there are differences in outcomes both by crops and by region. Table 10.1 summarizes the more recent projections for different crops in India. Overall, we see that by 2050 , projections estimate between $4 \%$ to $8 \%$ decrease in yields of crops at the minimum and around $25 \%$ decrease at the maximum. Regarding staple crops, we see that rice yields are expected to decrease by $4 \%$ and the productivity in the northwestern region, which is currently the high productivity belt for rice production, is extremely vulnerable to temperature changes. For wheat and sorghum too, experts estimate $6-7 \%$ decrease in overall productivity by 2050 due to increases in temperatures. Due to low adaptation capability of agricultural systems in the east, there are expected decreases in the productivity of horticultural crops such as coconut, potato and mustard. On the positive side, these productivity decreases may be offset by increases in productivity of the same crop groups in the south. Regarding staples, production and yields of wheat, maize and chick pea are thought to be most vulnerable especially in areas where crops are rain fed (Mall, Singh, Gupta, Srinivasan, \& Rathore, 2006; A. Sharma \& Pingali, 2016, 2018). However, for some non-staple crops such as pearl and finger millets, A. Sharma and Pingali (2018) find that climate change may be more detrimental due to the lack of availability of heat- and drought-resistant crop technology. Threats to 


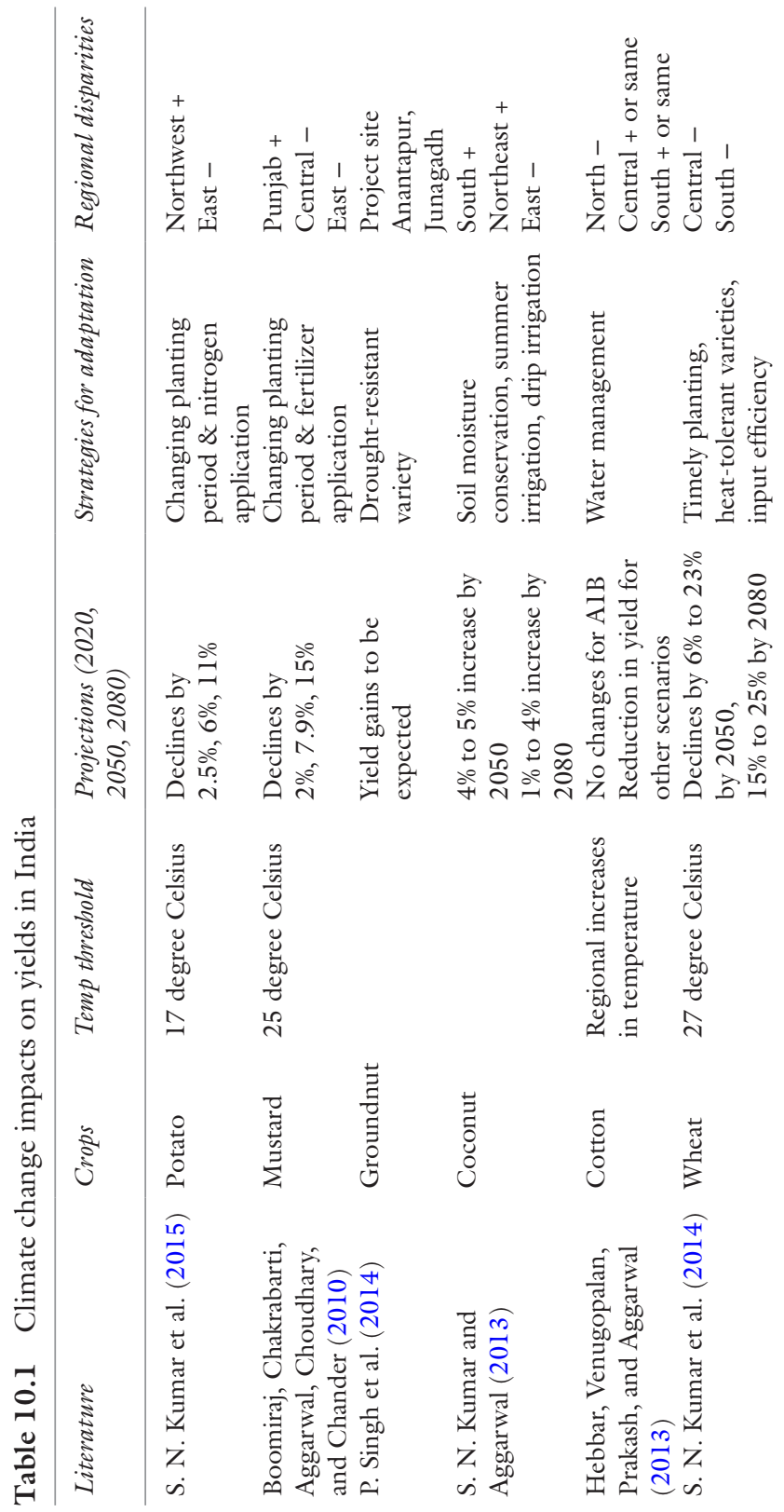



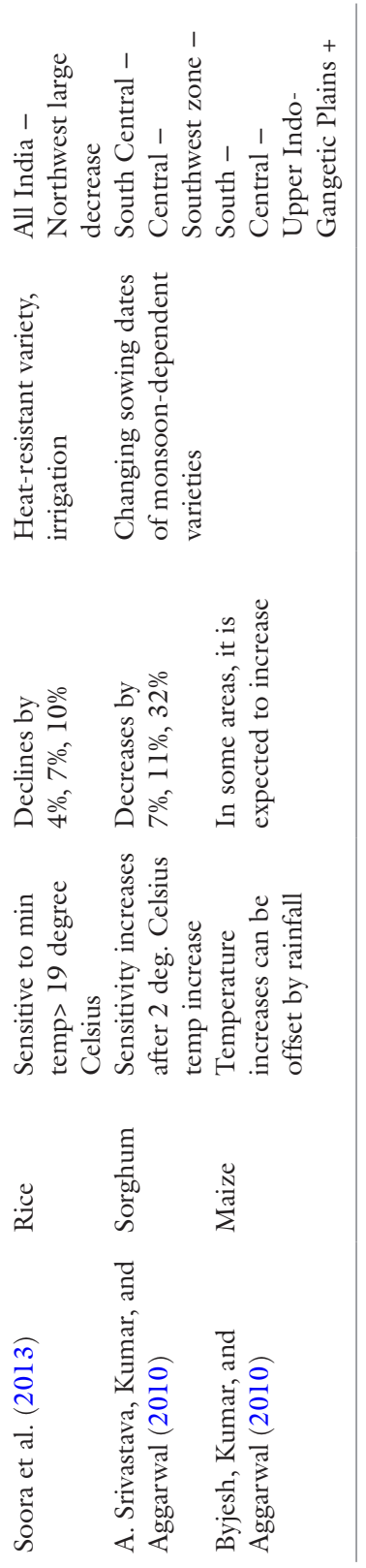
their production will have important implications for nutrient security as these crops (millets) are known to be the most important source of proteins and micronutrients in the diets of the poor.

The other caveats to keep in mind while talking about the benefits from climate change are the following. One, while many of the climate models used to make projections based on estimates to changes in seed technology and water availability, they do not account for increases in temperature that will make environmental conditions favorable for new pests, weeds and pathogens to thrive. The increased pestilence and pests resistant to current treatment options can have a major negative impact on crop productivity. The productivity impact of heat stress on agricultural inputs such as labor and livestock are also not accounted for in the projections. Two, in India, nearly $60 \%$ of all agricultural land continues to remain rain fed (Mall et al., 2006). Without appropriate groundwater management practices such as construction of aquifers, improvement of irrigation channels and prevention of acidification of soils, the impact of the changes on crops yields may be more devastating than what the models predict (Abraham \& Pingali, 2017; Brenkert \& Malone, 2005; Guhathakurta, Sreejith, \& Menon, 2011; O'Brien et al., 2004; Sinha \& Swaminathan, 1992). Three, while a large part of the scientific discourse has been focused on calorie security through investments in staple grains, the impacts of climate on the yields of non-staples and hence impacts on protein and micronutrient availability is less understood (A. Sharma \& Pingali, 2018). Many of the poor (and vegetarians) in India rely on non-staple crops for enhancing their nutritional diversity. Given the lack of technologies currently available to safeguard productivity and the lack of information about climate impacts on these types of crops, the vulnerability of nonstaple crop production becomes a major food security concern for the future. Safeguarding the production of these crops will be important in the goal of achieving nutrition security. This argument also extends towards yields of non-staple crops as well as yields of livestock and fisheries. For example, increasing sea temperatures are known to decrease yields of small fishes and increase the incidence of harmful cyanobacteria that will impact nutrition availability from these sources (Brenkert \& Malone, 2005; Paerl \& Paul, 2012). Changes in temperature are also expected to bring forth new pathogens that will affect zoonotic pathways within which human and livestock interact with each other, thus further impacting yields and productivity of livestock (Myers et al., 2017). These factors too may impact nutrient availability and hence the quality of food. 


\subsubsection{Impact on Biodiversity}

Forests, grasslands, marshes and their related ecological species play an important role in protecting food systems. The most important is their ability to mitigate some effects of climate change through carbon sequestration. For example, even though agriculture is thought to contribute to nearly $25 \%$ of the world's GHGs, nearly $20 \%$ of these emissions are reabsorbed by the bio-ecosystems around them (IPCC, 2014). Mature ecological systems are thus key to reducing the GHGs in the atmosphere and reducing the intensity of climate change on inputs in the food systems. Regarding benefits to agriculture and food production, bio-ecosystems play a major role in soil conservation. Forests prevent soil erosion and produce organic matter that can improve nutrient content in soils around them (R. R. Banerjee, 2015; Steiner, Briske, Brown, \& Rottler, 2018). Coastal marshes are also known to prevent excess flooding and acidification of soils in areas around them (Wigand et al., 2017). However, there are currently no market tools that can value the contributions of ecological systems services towards climate health and hence their value in food systems is underestimated. Even climate scientists do not account for the role of these systems in mitigation and adaptations strategies for global climate change, thus reducing global discussion on their preservation. This increases the vulnerability of bio-ecosystems to climate change which spills over as a greater vulnerability for food security.

\subsubsection{Impact on Price Volatility and Food Access}

In a country like India, having access to food is complicated by food price volatility (from production uncertainty) and inefficient food distribution systems. The former reduces the affordability of foods and the latter reduces access due to high rates of food loss and waste. Both these factors reduce access to nutrition in diets. With regard to the former, in combination with rising per capita demand for food, changing preferences towards more diverse diets and shrinking productivity and (or) food production, climate change increases uncertainty in the food supply and hence increases volatility in associated food prices. While a trend of rising prices may reflect increasing demand for food, increase in price volatility in the short run (due to shortfalls in production from extreme weather events) additionally widen the gap of access for the poor who have limited abilities to smooth consumption in times of price volatility. Another major contributor to price volatility is inefficient supply chains that are associated with high levels of food and nutrient loss as food moves from farm to plate. 
In a report by the FAO in 2011 on food loss and waste, it was estimated that nearly $90 \%$ of all food losses occurs in the supply chain process between the farms and the urban markets in South Asia. These losses contribute to the reduction in food and nutrient availability, thus exacerbating production shortfalls. Even as late as 2014 , inefficient supply chain processes of the PDS that were meant to supply adequate calories to individuals could not reach 194 million hungry people in India. ${ }^{4}$ This was in a year where the country produced a surplus of 40 million tons of staples.

Unexpected spikes in prices of food have been associated with increased incidence of conflicts (Bellemare, 2015; D'Souza \& Jolliffe, 2013; Hossain \& Green, 2011; J. Swinnen \& Squicciarini, 2012; C. P. Timmer, 1989), reduction in welfare of net consumers of food (Wodon \& Zaman, 2010) and lower diet quality in households (D'Souza \& Jolliffe, 2013). The unprecedented spikes in world food prices in 2008 due to energy related constraints was thought to have been an underlying factor in food riots across 23 countries. India, too, is also not a stranger to food inflation risks. Research has documented that food price volatility can impact an incumbent's political position during election cycles (Besley \& Burgess, 2002). In the past, when there have been production shortages, either locally or globally, the government of India has smoothened prices through the release of its own stocks as well as procuring from international markets to avoid such political upheavals (Besley \& Burgess, 2002; C. P. Timmer, 1989).

\subsubsection{Impacts on Health and Thus Future Labor Productivity}

Having good health has been linked to better educational outcomes, wages and labor productivity. More healthy individuals are more productive and can access opportunities to better their own and their family's circumstances. Climate change can affect the health of individuals, and hence labor productivity, by (1) increasing risks for malnutrition and by (2) increasing morbidity that spills over into poor health through the same channel. With regard to its direct effects, by reducing access to good quality food and foods with micronutrients, climate change can increase undernutrition, hidden hunger and obesity risks. Indirectly as well, by increasing risks of

\footnotetext{
${ }^{4}$ https://www.reuters.com/article/us-india-food-hunger/as-millions-go-hungry-indiaeyes-ways-to-stop-wasting-14-billion-of-food-a-year-idUSKBN1ET07Y (Accessed February 2018).
} 
vector-borne diseases (due to changes in temperature or precipitation) and non-communicable diseases (due to the changing health environment), climate change can increase risk factors related to malnutrition. These changes can lead to a vicious cycle of poor health and increased exposure to climate risks. As the health of individuals deteriorates, labor productivity of individuals will fall and this increases their exposure to income shocks that climate change may pose.

\subsubsection{Direct Impact on Malnutrition}

A more nuanced assessment of the impact of climate on food and nutrition security involves unpacking its implications on food quality. Quality, here, refers to access to a diet that reduces the incidence of the triple burden of malnutrition. Food system related interventions in the past have focused singularly on increasing the access to calories in order to reduce hunger and undernutrition. However, even as we have had some successes towards meeting the SDG targets of reducing calorie-related undernutrition, climate change has brought new problems to the center stage. First is the impact of climate change on undernutrition and hidden hunger. The majority of the poor in India depend on plant-based foods for proteins and micronutrients. With lower bio-availability of protein due to climate change, this can adversely affect protein related undernourishment (Myers et al., 2014). Lower micronutrient content in plants too will manifest itself in higher rates of anemia (Brabin, Hakimi, \& Pelletier, 2001; Kalaivani, 2009; Rasmussen, 2001; Yip, 2000). Two, prices of foods generally reflect calorie availability and not value from its nutrition content. Without an appropriate way to signal the value of nutrient diversity, prices of food will never reflect nutrition scarcity. Without this information, the research and business community may continue to focus on developing adaptive strategies to maintain calorie content for foods rather than developing nutrient rich crops. Lack of support for increasing diversity in diets by incentivizing greater production and consumption of non-staple foods (such as livestock, fisheries and non-staple crops) may lead to further degradation of diet diversity within households (P. Pingali, 2012, 2015; P. L. Pingali, Spielman, \& Zaidi, 2014). Three, without the proper incentives to develop nutrient rich food, individuals may face increases in obesity due to overconsumption of nutrient poor foods. All these factors would, in turn, impact nutrient absorption capability of individuals and hence affect the health of individuals. 


\subsubsection{Other Impacts on Health and Nutrition Access}

In addition to the direct climate impacts on nutrition availability, accessibility and quality, there are some indirect pathways through which climate can impact food security. With temperature increases across the globe, experts have predicted that there will be a spatial redistribution in the incidence of vector-borne diseases. Zoonotic diseases, diseases transmitted from animals to humans, that were traditionally found in warmer climates will become more common in colder areas (Patz, Campbell-Lendrum, Holloway, \& Foley, 2005). This includes the incidence of diseases such as malaria and other vector-borne diseases that are dependent on temperature, water, humidity and so on (Dhiman, Pahwa, Dhillon, \& Dash, 2010; Lindblade, Walker, Onapa, Katungu, \& Wilson, 2000; Paaijmans et al., 2010; Sutherst, 2004; Tanser, Sharp, \& le Sueur, 2003). Increase in morbidity from these diseases tends to affect the nutrition absorption capacity of individuals, thus impacting access to nutrition. In addition to the associated mortality risks, these diseases are also known to impact the health and productivity of individuals and thus economic development and food security (Watts et al., 2015). Climate stressors such as fires, heat waves, droughts and floods may bring with them heat stress, more particulate pollution, pollen allergens and change the composition of the ozone. These changes have been associated with increased risk of diseases of the respiratory systems, cardiovascular system and chronic and acute diseases such as cancer (Ebi \& McGregor, 2008; McMichael, Woodruff, \& Hales, 2006; Watts et al., 2015; Ziska et al., 2003). It has also been established in the literature that heat stress is a major cause for reduction in productivity (Ciais et al., 2005; Kjellstrom, Holmer, \& Lemke, 2009; Xiang, Bi, Pisaniello, \& Hansen, 2014). In the current research from India, air pollution and heat stress have been associated with reductions in crop yields (Auffhammer et al., 2006; J. Burney \& Ramanathan, 2014; R. Gupta et al., 2017), health effects such as increase in respiratory disorders and increases in mortality (Greenstone \& Hanna, 2014; Majra \& Gur, 2009; Ziska et al., 2003) as well as reduction in labor productivity (E. Somanathan, Somanathan, Sudarshan, \& Tewari, 2015). All these factors may contribute to affecting the health of individuals which may spill over as lower labor productivity. 


\subsubsection{Impacts on Long-Term GDP Growth}

In the previous two sections, we have presented evidence that climate change can have negative impacts on health and agriculture. In the short term, labor productivity losses from poor health and poor access to food reduce an individual's ability to access opportunities for enhancing their welfare. In the long term, by reducing the labor dividend from young populations, GDP growth prospects that depend on this resource will be negatively affected. Also, when agricultural systems perform poorly, structural transformation (ST) processes may be stunted as well. This, in turn, leads to some areas lagging behind and makes catch-up growth in the long term difficult. These spillovers aside, climate change can directly impact GDP growth. From a regional perspective, by changing comparative advantages of resources (land quality, labor quality, etc), climate change poses a major threat to ST prospects within the country. In the absence of access to appropriate adaptation technologies, some households may be more vulnerable than others. For example, households that are poor, households that depend on low-skilled labor for income generation and households headed by women may be more vulnerable to climate change if they cannot cope with its impacts. Within households as well, women and girl children may be more vulnerable if their human capital investments depended on good weather outcomes. These factors contribute to increasing income inequality across the country, thus reducing prospects for equitable growth. Further, as GDP growth stagnates, lower capacity to tide over events related to climate change may be reinforced. In this section, we bring together evidence with regard to climate impacts on economic growth prospects.

\subsubsection{Regional Losses from Climate Change on GDP}

From a global perspective, changes in climate have been linked to decreasing GDP growth rates under all scenarios of climate change. In some regions in the tropical South-such as countries in Africa-the effects are likely to be more severe. In scenarios of high adaptation to climate change, these growth rate declines are expected to be smaller, but overall, the climate community is of the opinion that the decreasing GDP growth rates are the reality of the future (Burke, Hsiang, \& Miguel, 2015; Dell, Jones, \& Olken, 2012; Lobell \& Burke, 2010; Nelson, Mensbrugghe et al., 2014). In India, vulnerability studies that assess the impact of climate change find that the northwest regions, the southern coastlines and hilly regions are especially vulnerable to climate change. Even though these 
regions are thought to have better adaptive capacity due to better education and higher incomes of the individuals living in these areas, changing weather patterns and increases in the sea levels are expected to negatively impact these regions more than the rest of the country (Jacoby, Rabassa, \& Skouas, 2011; Skoufias, Rabassa, \& Olivieri, 2011; E. Somanathan \& Somanathan, 2009). A regression of GDP on climate variables, controlling for the structural transformation experiences across states as well as historical advantages in development, shows us that increases in temperature of about one degree Celsius may have reduced GDP growth by more than 19 percentage points over the last four decades (Table 10.2). There are also differences across regions. For example, for states that are poor, increases in temperature and precipitation may have been beneficial for growth. For agricultural states, increases in precipitation may have reduced growth, and for urbanized states, temperature increases may have been beneficial.

\subsubsection{Impact on Communities and Households}

Even though the prospects for economic growth are dire for the future, the literature on the impact of climate change on poverty rates has shown that climate change may come with heterogeneous impacts for different groups. The two main channels through which climate is expected to impact household incomes is through prices and cost of production (Hertel, Burke, \& Lobell, 2010). If climate change increases the earning potential of the household relative to their costs, then some models do find that poverty rates of certain groups of individuals may decrease. In a paper by Hertel et al. (2010), the authors integrate household survey data into economic and climate change models to estimate the future impact on poverty. They find that in scenarios of low productivity where prices of food increase, poverty rates of farmers who are net sellers of food may reduce. Even in cases low prices, appropriate adaptation strategies may lower the burden of climate change on the agriculture community if agricultural productivity is high. For agricultural laborers, the results from the literature are mixed. L. Banerjee (2007) and E. Somanathan and Somanathan (2009) find that in times of flood, wages of hired help tended to increase in Bangladesh and India in the short term. However, E. Somanathan and Somanathan (2009) also found that in the medium term, these benefits are eroded as unemployment increases in these areas. In India, the impacts of increasing vagaries of the weather are known to negatively impact incomes and increase the vulnerability of those depending on the natural environment for their food security. Subsistence farmers or fisher folk with little financial capabilities to smooth over the production shortfalls created by 
Table 10.2 Regional impacts of climate change between 1970 and 2014

\begin{tabular}{|c|c|c|c|c|}
\hline \multirow[t]{2}{*}{ Variables } & (1) & (2) & (3) & (4) \\
\hline & $\operatorname{Modl}$ & $\operatorname{Mod} 2$ & Mod3 & $\operatorname{Mod} 4$ \\
\hline Mean_temperature & $\begin{array}{l}-6.309 \mathrm{e}+06^{* * *} \\
(1.117 \mathrm{e}+06)\end{array}$ & $\begin{array}{l}-6.309 \mathrm{e}+06^{* * *} \\
(1.117 \mathrm{e}+06)\end{array}$ & $\begin{array}{l}-0.193 * * * \\
(0.043)\end{array}$ & $\begin{array}{l}-0.193^{* * *} \\
(0.043)\end{array}$ \\
\hline Poor $\times$ Temp & $\begin{array}{l}1.946 \mathrm{e}+06 \\
(1.868 \mathrm{e}+06)\end{array}$ & $\begin{array}{l}1.946 \mathrm{e}+06 \\
(1.868 \mathrm{e}+06)\end{array}$ & $\begin{array}{l}0.131^{*} \\
(0.071)\end{array}$ & $\begin{array}{l}0.131^{*} \\
(0.071)\end{array}$ \\
\hline $\mathrm{Ag} \times \mathrm{Temp}$ & $\begin{array}{l}6.982 \mathrm{e}+06 * * * \\
(1.368 \mathrm{e}+06)\end{array}$ & $\begin{array}{l}6.982 \mathrm{e}+06^{* * *} \\
(1.368 \mathrm{e}+06)\end{array}$ & $\begin{array}{l}0.0350 \\
(0.053)\end{array}$ & $\begin{array}{l}0.035 \\
(0.053)\end{array}$ \\
\hline $\mathrm{Urb} \times \mathrm{Temp}$ & $\begin{array}{l}1.063 \mathrm{e}+07 \text { * * * } \\
(1.786 \mathrm{e}+06)\end{array}$ & $\begin{array}{l}1.063 \mathrm{e}+07^{* * *} \\
(1.786 \mathrm{e}+06)\end{array}$ & $\begin{array}{l}0.109 * \\
(0.063)\end{array}$ & $\begin{array}{l}0.109 * \\
(0.063)\end{array}$ \\
\hline Mean_precipitation & $\begin{array}{l}-2,859 \\
(7,489)\end{array}$ & $\begin{array}{l}-2,859 \\
(7,489)\end{array}$ & $\begin{array}{l}-0.001 \\
(0.00)\end{array}$ & $\begin{array}{l}-0.001 \\
(0.00)\end{array}$ \\
\hline Poor $\times$ Precip & $\begin{array}{l}-13,884 \\
(19,517)\end{array}$ & $\begin{array}{l}-13,884 \\
(19,517)\end{array}$ & $\begin{array}{l}0.002 * * * \\
(0.001)\end{array}$ & $\begin{array}{l}0.002 * * * \\
(0.001)\end{array}$ \\
\hline Ag $\times$ Precip & $\begin{array}{l}-27,257^{* *} \\
(12,511)\end{array}$ & $\begin{array}{l}-27,257^{* *} \\
(12,511)\end{array}$ & $\begin{array}{l}-0.001 * * \\
(0.001)\end{array}$ & $\begin{array}{l}-0.001 * * \\
(0.001)\end{array}$ \\
\hline Urb $\times$ Precip & $\begin{array}{l}50,569 * * \\
(25,584)\end{array}$ & $\begin{array}{l}50,569 * * \\
(25,584)\end{array}$ & $\begin{array}{l}0.000 \\
(0.001)\end{array}$ & $\begin{array}{l}0.000 \\
(0.001)\end{array}$ \\
\hline Constant & $\begin{array}{l}-1.310 \mathrm{e}+08^{* * *} \\
(4.949 \mathrm{e}+07)\end{array}$ & $\begin{array}{l}6.459 \mathrm{e}+07 \\
(5.418 \mathrm{e}+07)\end{array}$ & $\begin{array}{l}16.51^{* * *} \\
(1.402)\end{array}$ & $\begin{array}{l}21.58 * * * \\
(1.617)\end{array}$ \\
\hline Observations & 1,340 & 1,340 & 1,340 & 1,340 \\
\hline$R$-squared & 0.818 & 0.818 & 0.992 & 0.992 \\
\hline State FE & Yes & Yes & Yes & Yes \\
\hline Region year FE & Yes & Yes & Yes & Yes \\
\hline Poor state year FE & Yes & Yes & Yes & Yes \\
\hline Robust SE & Yes & Yes & Yes & Yes \\
\hline HAP dummy & No & Yes & No & Yes \\
\hline URB dummy & No & Yes & No & Yes \\
\hline Poor dummy & No & Yes & No & Yes \\
\hline
\end{tabular}

Robust standard errors are in parentheses. Models are panel fixed effects with the state being the key crosssectional variation while year being the time series variation. Stars indicate the following: ${ }^{* *} p<0.01$, ${ }^{* *} p<0.05,{ }^{*} p<0.1$

This table uses a panel of information on state-wise climate and GDP data (annual) between 1970 and 2013 coming from multiple sources. [This dataset includes all years for which there is complete information for constructing the panel. Union territories of Dadra and Nagar Haveli, Lakshadweep and Daman and Diu did not have GDP data. For states formed only after 2000, the GDP of the parent state was assigned before it was formed. The climate data has already accounted for this transition of the state.] Temperature and precipitation data were downloaded using the AidGeo dataset available at http://geo. aiddata.org/query/\#!/. For state GDP data, I have used the information collated from the EPW Research Foundation. [http://www.epwrfits.in/index.aspx GDP values have been converted to constant prices in 2004-05 rupees for comparability across years.] State FE captures within state variation. Region year FE captures changes across regions and years. Here states are coded as being in north, south, northeast, northwest and west based on their geographical location. Poor state year fixed effects control for the differential experience of states which have had low ST experience (also referred to as lagging states) due to their inherent disadvantages. The Ag dummy captures the experience of states which have highly productive agricultural systems (as defined in Chap. 2), URB dummy captures those states with high levels of ST 
weather-related risks are often forced into debt when they borrow high interest loans from the informal sectors (R. M. Townsend, 1994). The recent protests in Delhi that were organized by farmers to discuss relief packages for extended drought cycles in Tamil Nadu reflect on the intensity of this problem. ${ }^{5}$ Among the class of individuals who are expected to be the most vulnerable to climate change are the urban wage laborers. Regardless of whether the world realizes high or low adaptation scenarios, authors have found that this group will be negatively impacted both in terms of their earning shares and cost of living (Ahmed, Diffenbaugh, \& Hertel, 2009; Hertel et al., 2010; Pettengell, 2010; Skoufias et al., 2011).

Most estimates of the impacts of climate change, however, tend to underestimate the negative impacts. There are many reasons for this. For one, many of these models assume too simply that the poverty line of today is a good representation of the poverty line for the future. Reducing poverty rates by moving people above the current poverty line does not account for their increased vulnerability to extreme events and the increasing costs that are associated with the same. Two, these models have simplistic assumptions on the nature of the damage functions and assume the low probability of catastrophic events. This leads them to underestimate the risks involved (Pindyck, 2013; Pindyck \& Wang, 2013; Weitzman, 2014). Three, climate models do not account for changing urbanization patterns and thus tend to underestimate how many people will actually be vulnerable and poor in the future and hence the depth of the problem. Four, effects of climate changes are believed to impact different areas with different intensity. For example, many of the studies have shown that the northwest of India, that is traditionally associated with high agricultural productivity, may be more vulnerable to climate changes than the east (Jacoby et al., 2011; O'Brien et al., 2004; E. Somanathan \& Somanathan, 2009). Hence, agricultural households in these areas may be more vulnerable. Also, the southern states are more vulnerable to changes in sea levels which will affect the livelihoods and poverty rates of populations subsisting on the coastlines (Brenkert \& Malone, 2005). These differences in experiences will complicate the policy landscape on how to bolster the livelihoods of groups who are impacted by climate change.

\subsubsection{Impact on Individuals Within Households}

Within households, gender, age, cultural norms and social and economic constraints tend to exacerbate the problem of food access in the face of climate change. Women in households are particularly disadvantaged in

\footnotetext{
${ }^{5}$ http://www.bbc.com/news/world-asia-india-39650496
} 
these situations since inaccurate economic values associated with their contributions to the household, cultural norms and social expectations tend to exacerbate the problem of poor access. Without appropriate safety nets such as conditional cash transfers and so on in the event of major weather shocks, such as rainfall shocks, women of the household often bear the brunt of the reduction in food security of households (Demeke, Keil, \& Zeller, 2011; Gladwin, Thomson, Peterson, \& Anderson, 2001). For those women who survive through tough times such as droughts and famines with limited access to resources, the intergenerational impacts of poor health are transmitted to their children, thus perpetuating disadvantages of these events (Dyson \& Maharatna, 1992; J. Hoddinott \& Kinsey, 2001; Shah \& Steinberg, 2012). Microeconomic analysis of households shows that nutrition outcomes of children too tend to be drastically affected during times of droughts and famines. These poor outcomes tend to persist into adulthood, where children who have been through famines have lower educational outcomes, wages and health (Chen \& Zhou, 2007; C. Huang, Li, Wang, \& Martorell, 2010; Luo, Mu, \& Zhang, 2006; T. Roseboom, de Rooij, \& Painter, 2006; T. J. Roseboom et al., 2001). Girls are often at higher risks to these shocks. The literature has shown, for example, that only when there are good years for rain, farming households increase investments in education and health for female children. In times of drought, authors find that household members reallocate scarce human capital resources away from female children towards male children within households (Baird, McIntosh, \& Özler, 2011; Bonesrønning, 2010; J. Hoddinott \& Kinsey, 2001; Maccini \& Yang, 2009; Verwimp, 2012). This is often reflected in poorer health outcomes of girl children regarding malnutrition indicators. Thus, these groups tend to be more vulnerable to climate change.

\subsection{Managing Current and Future Climate RisKS FOR INDIA}

Looking ahead, we see that climate change risks pose a major threat to current and future food systems in India. Evidence documented on its risks on health, agriculture and economic development suggests that it is important to take this threat seriously as we envision food systems of the future. Also, the Indian subcontinent has seen a rapid increase in extreme weather events and unprecedented changes to weather and pollution rates. These events call upon the urgency to address the impacts of climate change. 
In this section, we outline India's commitment to climate change mitigation and provide some recommendations on how climate policies can be focused towards enabling nutrition-secure food systems. In the next chapter, we provide a more detailed discussion on policy options in this regard.

\subsubsection{Quantifying India's Contribution Towards Climate Change}

Based on data from the World Bank DataBank, India was the third largest emitter of carbon dioxide, following China and the United States in 2014 (Fig. 10.3). Within India, the MoEF (2010) report ${ }^{6}$ concluded that the energy sector contributed to around $60 \%$ of the total emissions with nearly two-thirds of the emissions coming from electricity generation through the use of coal. Emissions from the transport and residential sector made up around one-fourth of total emissions from the same sector. While the

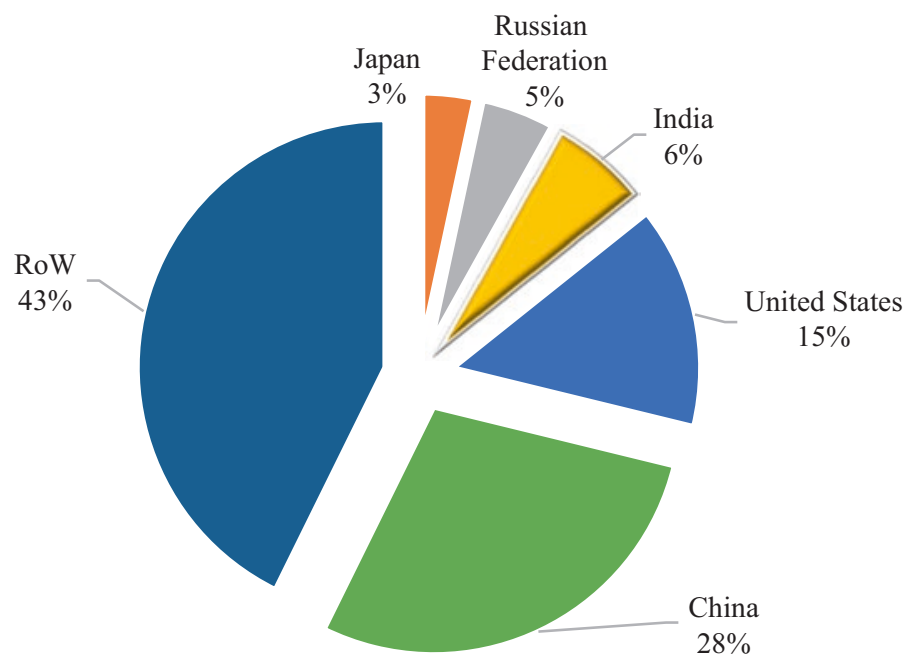

Fig. 10.3 Share of $\mathrm{CO}_{2}$ (total) emissions by country in 2014. Source: World Bank DataBank; based on authors calculations

\footnotetext{
${ }^{6}$ Note that there have been no updates to these numbers since then. All the new MoEF reports continue to refer to these numbers.
} 


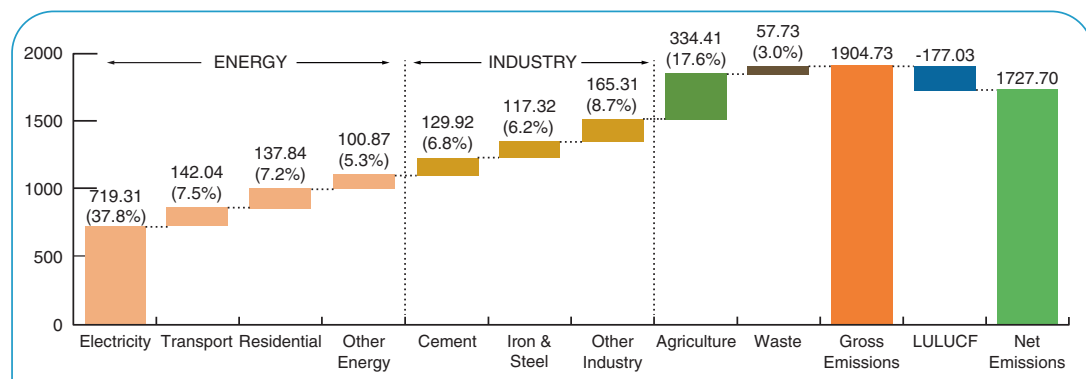

Note:

Other Energy: includes GHG emissions from petroleum refining, manufacturing of solid fuel, commercial \& institutional sector, agriculture \& fisheries and fugitive emissions from mining, transport and storage of coal, oil and natural gas.

Other Industry: includes GHG emissions from production of glass and ceramics, soda ash, ammonia, nitric acid, carbides,

titanium dioxide, methanol, ethylene oxide, acrylonitrile, carbon black, caprolactam, ferro alloys, aluminium, lead, zinc, copper, pulp and paper, food processing, textile, leather, mining and quarrying, non specific industries and use of lubricants and paraffin wax. Agriculture: includes GHG emissions from livestock, rice cultivation, agricultural soils and burning of crop residue.

Waste: includes GHG emissions from municipal solid waste (MSW), industrial and domestic waste water.

LULUCF: includes GHG emissions and removals from changes in forest land, crop land, grass land, wet land, settlements and combustion of fuel wood in forests.

Figure ES1: GHG emissions by sector in 2007 (million tons of $\mathrm{CO}_{2}$ eq). Figures on top indicate the emissions by sectors and in brackets indicate \% of emission of the category with respect to the net $\mathrm{CO}_{2}$ equivalent emissions. See glossary for definition of $\mathrm{CO}_{2}$ equivalent.

Fig. 10.4 Emission by sectors. Source: Ministry of Environment \& Forestry report, 2009

agricultural sector contributed to around $18 \%$ of the emissions, nearly $64 \%$ of the emissions came from the livestock sector and $21 \%$ from rice cultivation (Fig. 10.4). Construction materials accounted for nearly $60 \%$ of the total industrial emission. Municipal, domestic and industrial waste made up around one-third of the emissions from waste. Among other factors that have contributed to GHGs are excessive deforestation and land clearing that have reduced the number of carbon sinks ${ }^{7}$ across the country. In 2009 , less than $10 \%$ of all emissions from the country were reabsorbed by these carbon sinks. This rapid growth of emissions is documented in Fig. 10.5, where one sees that both total emissions and per capita emissions have been increasing over time. In a projection exercise conducted by the Ministry of Environment, Forests and Climate Change (MoEF, 2008 ), it was estimated that per capita emissions in India would be around 4-5 tons per capita by 2030, a threefold increase after 2009. This would

${ }^{7}$ Carbon sinks are natural or artificial reservoirs that absorb and store atmospheric carbon with physical and biological mechanisms. Forests and land covered with vegetation are one type of carbon sink. 


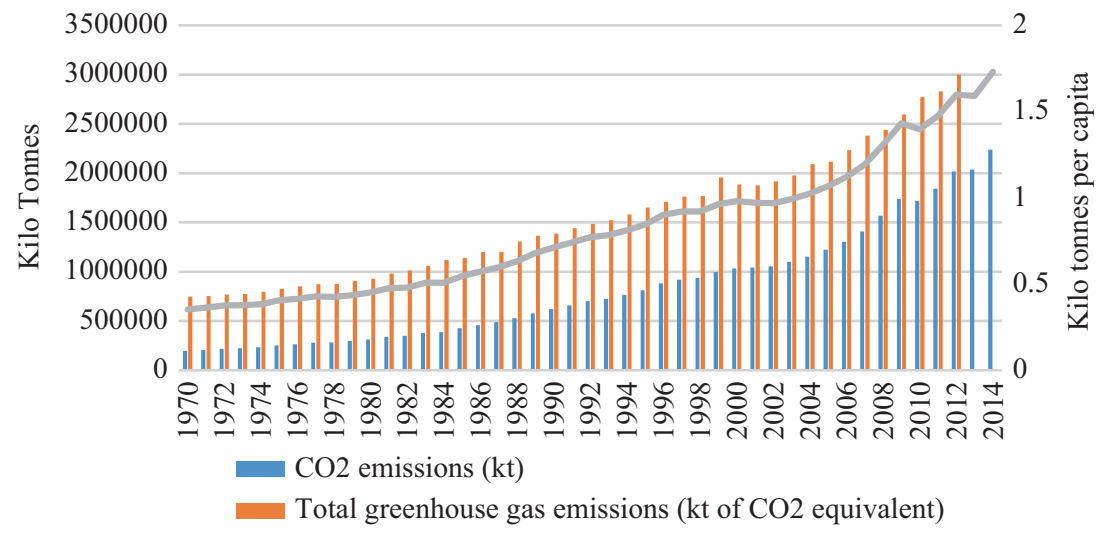

Fig. 10.5 Overview of GHG emissions in India. Source: World Bank DataBank; based on authors calculations

imply that global emissions from India would be around 6 billion tons (higher than United States emissions for 2014). Given the climate sensitivity to these irreversible emissions, Indian and global food systems face a major threat from the current Indian economic growth experience.

\subsubsection{Overview of India's Commitment Towards Mitigation and Reduction of GHG Emissions}

In recognition of the local and global impacts of climate change and the role of India as one of the largest emitters of GHGs, policy makers have been working towards creating policies to reduce GHG emissions across its economic sectors. After ratifying its commitment towards climate change mitigation in the Paris agreement, the central government and the state governments have put forth comprehensive action plans that outline strategies, goals and priorities towards reducing GHG emissions to cut India's emissions by $25 \%$ in 2020 . To do so, policy makers have committed to promoting clean and efficient energy use in the power sector, industrial sectors and urban housing, increasing a number of carbon sinks and investing in sustainable agricultural practices. With regard to the power sector, replacing the current capacity for coal-generated power with solar energy and renewable energy provision has become a national priority. Large investments have been made in the wind and solar energy sector, which 
now provides around $14 \%$ of all power within the country. ${ }^{8}$ With regard to household level clean energy production, the government has taken important steps to reduce firewood dependence by introducing alternative cost-effective clean energy technologies such as biogas fuels and solardependent cooking stoves in rural areas. Urban-focused initiatives that seek to reduce emissions through investments in green infrastructure housing projects and reduce solid waste in cities through investments proper disposal infrastructure are under way in many areas. ${ }^{9}$ There have been efforts made towards fully converting public transport vehicles to using low emissions fuels, and subsidies towards adopting clean energy private vehicles are in place. The government has also introduced a program called the "Perform, Achieve and Trade" that sets caps on GHGs and particulate emissions on industries across the country. Industries can trade their E-Certificates through a regulated exchange to achieve compliance obligations and reduce non-compliance penalties. In states where healthrelated concerns from communicable diseases are a threat to population health, investments in improving health infrastructure, services and access to health technology have been proposed. Many states have also proposed moving agricultural systems towards organic farming practices, investing in water conservation technologies, improving management practices with regard to livestock and investing in research and development focused on technologies for climate adaptation in the agricultural sector as a means to reduce damages from climate uncertainties. At the national level, improving biodiversity and vegetation cover through initiatives for reforestation, protecting forest areas from exploitation as well as working with communities through decentralized forms of governance of natural resources have been proposed. Also, there have been proposals to develop climate-smart strategies that finance research in developing heat- and drought-resistant varieties of crops, setting up disaster management systems, instituting weather-based insurance programs and desilting irrigation systems to improve water management and to improve management of forest and coastal ecology. These investments are also thought to play a role in GHG reductions from the agricultural sectors as well as help in increasing the

\footnotetext{
${ }^{8}$ India is one of the largest producers of electricity through wind energy in the world.

${ }^{9}$ Building regulations to construct environment friendly urban infrastructure that are energy efficient have been encouraged and regulations for industrial waste management and recycling of solid waste have been introduced as a part of mitigation strategies (MoEF, 2008). A comprehensive commentary on the policies under the NAPCC and the actions taken by the government can be found in the reference (J. Ahmad, 2013).
} 
capacity to adapt. The commitments made towards various initiatives both at the national and the state level can be found in national and state action plan towards reducing the impact of climate change, respectively. In these comprehensive documents, a summary of these actions proposed and the funds allocated towards each topic can be found. These strong commitments made have put India in a leadership position in talks on tackling climate change on the global stage.

\subsubsection{Refocusing Climate Change Policies Towards Tackling Risks for Food Systems}

While India's climate mitigation strategies have been extremely progressive, in this chapter, we have highlighted the risks that climate change poses to current and future food systems. Extreme weather events in the country have increased the urgency to design and implement adaptation strategies in response to climate change. The process involves assessing vulnerabilities of different stakeholders in food systems and supporting them to develop capabilities to respond to the uncertainties both in the current time and as we look ahead. The ability to adopt strategies to deal with climate change is known to be a function of an individual's wealth, capabilities, access to market and access to knowledge and technology. These factors determine the individual's vulnerability to climate change, that is, how much they are likely to be affected, and their resilience against uncertainties, that is, how much they can cope with these changes (Hallegatte, 2009; Pettengell, 2010; B. Smit, Burton, Klein, \& Wandel, 2000; B. Smit \& Wandel, 2006). From a food systems perspective, ensuring food and nutrition security of individuals thus requires strategies that both increase the availability of welfare-enhancing goods and ensure that adequate safety nets exist to improve current levels of access (Campbell et al., 2016; Lobell et al., 2008; Myers et al., 2017; Vermeulen et al., 2012). Investments in reducing production uncertainty, improving labor productivity through investments in health and food access and introducing policies to reduce inequities in access will be important for future adaptation policies meant to reduce the negative impact of climate change. Part of the challenge for adaptation strategies is to prioritize which policies will yield immediate returns and which policies are expected to yield benefits in the long run. This requires consolidating the evidence of adaptation strategies within India currently as well as identifying new ways to 
evaluate and compare the relative benefits of different strategies. Investing in research and development for technologies that increase productivity while reducing GHG emissions, encouraging participation of local communities in biodiversity preservation, sharing technology and resources across regional and national borders and encouraging investments in climate smart businesses will also be key features of successful mitigation strategies for the future. In the next chapter, we discuss some of the options available for moving the country towards a more nutrition-secure future as climate change increases food systems risk.

\subsubsection{Moving Beyond Strategies and Towards Concrete Measureable Actions}

A major concern for many intellectuals has been the lack of commitment to pursue these strategies to their full potential. For one, many of these strategies remain top down with the government setting goals without involving the communities affected. This approach has increased inefficiencies in implementation and in many cases caused well-meaning projects to fail. Even despite their best efforts, the government has not been able to reduce the rate of deforestation in the country since it has not involved the forest communities in conservation efforts (J. Ahmad, 2013; E. Somanathan et al., 2009). Two, due to corruption and the lack of transparency, well-designed plans to contain and recycle waste often fall to the wayside. The environmental protection agency in India is often not considered to be reliable in monitoring industries and has been known to turn a blind eye towards health concerns of communities who are affected by the location of the industrial plants (Dutta, Ghosh, Gopalakrishnan, Bijoy, \& Yasmin, 2013). This has affected the compliance of industries and increased inefficiency in carbon trading. Three, many of these plans on close reading reveal that there are no measureable outcomes defined in these action plans that would help monitor climate centric efforts and their outcomes. Without metrics to measure mitigation, it becomes difficult to measure progress. This reduces the incentive to commit and participate in the mitigation strategies for both individuals and industries. Four, without property rights, communities that subsist on the environment have no incentive to lobby for better environmental practices in their areas. This has prevented the integration of individuals into trading carbon credits in the climate market, a potentially important channel through which mitigation 
can be integrated globally (J. Ahmad, 2013; E. Somanathan et al., 2009). Five, there has been very little commitment towards developing technology or investing in business driven solutions that reduce climate dependence. Introducing climate-smart agricultural services that increase yields and reduce environmental degradation has not found their way into mainstream mitigation and adaptation strategies. Developing cost-effective technology or supporting businesses that invest in environment-friendly urban development has not taken off. This has prevented well-conceived strategies for mitigation from becoming self-sustaining (J. Ahmad, 2013; Dutta et al., 2013; Ray, 2011; E. Somanathan et al., 2009).

\subsection{Conclusion}

In this chapter, we identify the pathways through which climate change will impact nutrition security in India. Synthesizing the scientific evidence on climate change and its ongoing and future impacts on food availability, labor productivity and long-term economic growth in India, we highlight its role in reducing the effectiveness of food systems in ensuring nutrition security. For food availability, for example, we present evidence that changing temperature and rainfall patterns have begun to impact crop and livestock productivity across the country. Without adequate adaptation capabilities, future production capacity will decrease and the probability of facing production shocks will increase. Lower availability of food and thus nutrients will increase malnutrition by reducing access to food diversity. Similarly, by increasing susceptibility to communicable and noncommunicable diseases, climate change will increase malnutrition by reducing individual's capacity to absorb nutrients from food that may be available for consumption. These factors will combine to reduce the overall health and hence labor productivity. Poor health, low labor productivity and low productive agricultural systems will in turn impact long-term growth prospects by reducing the ability of economies to undergo a structural transformation, thus leading to stunted growth. Finally, we present evidence that climate change will increase vulnerability of regions by changing their comparative advantages, will increase the vulnerability of households by affecting health and will reinforce intra-household inequities in access. Continuing down the current path of development without integrating appropriate adaptation strategies, we argue, will have serious negative repercussions on nutrition security within the country. Side by side with adaptation strategies, integrating mitigation strategies that 
reduce the overall carbon foot print will not only contribute to the global goals of GHG mitigation, it will thus help reduce food systems risks related to nutrition security.

Currently, India is one of the countries leading discussions on climate change mitigation due to its forward-looking policies that encourage investments in clean energy sources, climate-smart infrastructure, preservation and conservation of biodiversity and ground water management processes. Both the central and state governments have focused attention on addressing this development challenge by increasing investments in renewable sources for energy generation. However, many other policies remain academic and their implementation has been slow. In order to cement India's position as a leader in climate change discussions on the global stage, moving these policies from desk to field will be important. As we look ahead, we also argue that climate policies for the future should allow diversification of the food system in ways that enhance the environment while improving the nutrition content of foods produced and ensuring equity in access. This discussion is currently lacking in the policy circles. To truly create a food system that ensures nutrition security of all individuals, we submit that climate change risks must not be understated and appropriate actions towards its mitigation need to be urgently adopted.

\section{REFERENCES}

Abraham, M., \& Pingali, P. (2017). Transforming smallholder agriculture to achieve the SDGs. In L. Riesgo, S. Gomez-Y-Paloma, \& K. Louhichi (Eds.), The role of small farms in food and nutrition security. Springer.

Ahmad, J. (2013). Climate change and sustainable development in India. New Century Publications.

Ahmed, S. A., Diffenbaugh, N. S., \& Hertel, T. W. (2009). Climate volatility deepens poverty vulnerability in developing countries. Environmental Research Letters, 4(3), 34004.

Auffhammer, M., Ramanathan, V., \& Vincent, J. R. (2006). Integrated model shows that atmospheric brown clouds and greenhouse gases have reduced rice harvests in India. Proceedings of the National Academy of Sciences, 103(52), 19668-19672.

Baird, S., McIntosh, C., \& Özler, B. (2011). Cash or condition? Evidence from a cash transfer experiment. Quarterly Journal of Economics, 126(4), 1709-1753. https://doi.org/10.1093/qje/qjr032

Banerjee, L. (2007). Effect of flood on agricultural wages in Bangladesh: An empirical analysis. World Development, 35(11), 1989-2009. 
Banerjee, R. R. (2015). Farmers' perception of climate change, impact and adaptation strategies: A case study of four villages in the semi-arid regions of India. Natural Hazards, 75(3), 2829-2845.

Bellemare, M. F. (2015). Rising food prices, food price volatility, and social unrest. American Journal of Agricultural Economics, 97(1), 1-21. https://doi. org/10.1093/ajae/aau038

Besley, T., \& Burgess, R. (2002). The political economy of government responsiveness: Theory and evidence from India. The Quarterly Journal of Economics, $117(4), 1415-1451$.

Bonesrønning, H. (2010). Are parental effort allocations biased by gender? Education Economics, 18(3), 253-268. https://doi.org/10.1080/ 09645290902843514

Boomiraj, K., Chakrabarti, B., Aggarwal, P. K., Choudhary, R., \& Chander, S. (2010). Assessing the vulnerability of Indian mustard to climate change. Agriculture, Ecosystems \& Environment, 138(3-4), 265-273.

Brabin, B. J., Hakimi, M., \& Pelletier, D. (2001). An analysis of anemia and pregnancy-related maternal mortality. The Journal of Nutrition, 131(2), 604S-615S.

Brenkert, A. L., \& Malone, E. L. (2005). Modeling vulnerability and resilience to climate change: A case study of India and Indian states. Climatic Change, 72(1), 57-102. https://doi.org/10.1007/s10584-005-5930-3

Burke, M., Hsiang, S. M., \& Miguel, E. (2015). Global non-linear effect of temperature on economic production. Nature, 527(7577), 235-239.

Burney, J., \& Ramanathan, V. (2014). Recent climate and air pollution impacts on Indian agriculture. Proceedings of the National Academy of Sciences, 111(46), 16319-16324.

Byjesh, K., Kumar, S. N., \& Aggarwal, P. K. (2010). Simulating impacts, potential adaptation and vulnerability of maize to climate change in India. Mitigation and Adaptation Strategies for Global Change, 15(5), 413-431.

Campbell, B. M., Vermeulen, S. J., Aggarwal, P. K., Corner-Dolloff, C., Girvetz, E., Loboguerrero, A. M., ... Wollenberg, E. (2016). Reducing risks to food security from climate change. Global Food Security, 11, 34-43. https://doi. org/10.1016/j.gfs.2016.06.002

Challinor, A. J., Watson, J., Lobell, D. B., Howden, S. M., Smith, D. R., \& Chhetri, N. (2014). A meta-analysis of crop yield under climate change and adaptation. Nature Climate Change, 4(4), 287.

Chen, Y., \& Zhou, L.-A. (2007). The long-term health and economic consequences of the 1959-1961 famine in China. Journal of Health Economics, 26(4), 659-681.

Ciais, P., Reichstein, M., Viovy, N., Granier, A., Ogée, J., Allard, V., ... Carrara, A. (2005). Europe-wide reduction in primary productivity caused by the heat and drought in 2003. Nature, 437(7058), 529-533. 
Cruz, R. V., Harasawa, H., Lal, M., Wu, S., Anokhin, Y., Punsalmaa, B., ... Ninh, N. H. (2007). Asia. In M. L. Parry, O. F. Canziani, J. P. Palutikof, P. J. van der Linden, \& C. E. Hanson (Eds.), Climate change 2007: Impacts adaptation and vulnerability. Contribution of Working Group II to the Fourth Assessment Report of the Intergovernmental Panel on Climate Change (pp. 469-506). Cambridge: Cambridge University Press.

D'Souza, A., \& Jolliffe, D. (2013). Conflict, food price shocks, and food insecurity: The experience of Afghan households. Food Policy, 42, 32-47. https:// doi.org/10.1016/j.foodpol.2013.06.007

Dell, M., Jones, B. F., \& Olken, B. A. (2012). Temperature shocks and economic growth: Evidence from the last half century. American Economic Journal: Macroeconomics, 4(3), 66-95.

Demeke, A. B., Keil, A., \& Zeller, M. (2011). Using panel data to estimate the effect of rainfall shocks on smallholders food security and vulnerability in rural Ethiopia. Climatic Change, 108(1-2), 185-206.

Dhiman, R. C., Pahwa, S., Dhillon, G. P. S., \& Dash, A. P. (2010). Climate change and threat of vector-borne diseases in India: Are we prepared? Parasitology Research, 106(4), 763-773. https://doi.org/10.1007/s00436-010-1767-4

Dietterich, L. H., Zanobetti, A., Kloog, I., Huybers, P., Leakey, A. D. B., Bloom, A. J., ... Hasegawa, T. (2014). Increasing $\mathrm{CO}_{2}$ threatens human nutrition. Scientific Data, 2, 150036.

Dutta, S., Ghosh, S., Gopalakrishnan, S., Bijoy, C. R., \& Yasmin, H. (2013). Climate change in India: Analysis of political economy \& impact. New Delhi: Rosa Luxemburg Stiftung-South Asia.

Dyson, T., \& Maharatna, A. (1992). Bihar famine, 1966-67 and Maharashtra drought, 1970-73: The demographic consequences. Economic and Political Weekly, 27(26), 1325-1332.

Ebi, K. L., \& McGregor, G. (2008). Climate change, tropospheric ozone and particulate matter, and health impacts. Environmental Health Perspectives, $116(11), 1449$.

Gladwin, C. H., Thomson, A. M., Peterson, J. S., \& Anderson, A. S. (2001). Addressing food security in Africa via multiple livelihood strategies of women farmers. Food Policy, 26(2), 177-207.

Greenstone, M., \& Hanna, R. (2014). Environmental regulations, air and water pollution, and infant mortality in India. American Economic Review, 104(10), 3038-3072.

Guhathakurta, P., Sreejith, O. P., \& Menon, P. A. (2011). Impact of climate change on extreme rainfall events and flood risk in India. Journal of Earth System Science, 120(3), 359. https://doi.org/10.1007/s12040-011-0082-5

Gupta, R., Somanathan, E., \& Dey, S. (2017). Global warming and local air pollution have reduced wheat yields in India. Climatic Change, 140(3-4), 593-604. 
Hallegatte, S. (2009). Strategies to adapt to an uncertain climate change. Global Environmental Change, 19(2), 240-247.

Hebbar, K. B., Venugopalan, M. V., Prakash, A. H., \& Aggarwal, P. K. (2013). Simulating the impacts of climate change on cotton production in India. Climatic Change, 118(3-4), 701-713.

Hertel, T. W., Burke, M. B., \& Lobell, D. B. (2010). The poverty implications of climate-induced crop yield changes by 2030. Global Environmental Change, 20(4), 577-585.

Hoddinott, J., \& Kinsey, B. (2001). Child growth in the time of drought. Oxford Bulletin of Economics and Statistics, 63(4), 409-436. https://doi. org/10.1111/1468-0084.t01-1-00227

Hossain, N., \& Green, D. (2011). Living on a Spike: How is the 2011 food price crisis affecting poor people? Oxfam Policy and Practice: Agriculture, Food and Land, 11(5), 9-56.

Huang, C., Li, Z., Wang, M., \& Martorell, R. (2010). Early life exposure to the 1959-1961 Chinese famine has long-term health consequences. The Journal of Nutrition, 140(10), 1874-1878.

IMD. (2018). Seasonal outlook for the temperatures during March to May 2018. Retrieved from http://www.imd.gov.in/pages/press_release_view.php?ff= 20180228_pr_205

IPCC. (2014). Mitigation of climate change. Contribution of Working Group III to the Fifth Assessment Report of the Intergovernmental Panel on Climate Change. Cambridge, UK and New York.

Jacoby, H. G., Rabassa, M., \& Skouas, E. (2011). Distributional implications of climate change in India.

Kalaivani, K. (2009). Prevalence \& consequences of anaemia in pregnancy. Indian Journal of Medical Research, 130(5), 627-633.

Kattelmann, R. (2003). Glacial lake outburst floods in the Nepal Himalaya: A manageable hazard? Natural Hazards, 28(1), 145-154.

Kjellstrom, T., Holmer, I., \& Lemke, B. (2009). Workplace heat stress, health and productivity-An increasing challenge for low and middle-income countries during climate change. Global Health Action, 2(1), 2047.

Kothawale, D. R., \& Rupa Kumar, K. (2005). On the recent changes in surface temperature trends over India. Geophysical Research Letters, 32(18). https:// doi.org/10.1029/2005GL023528

Kumar, A., Yadav, C., Jee, S., Kumar, S., \& Chauhan, S. (2011). Financial innovation in Indian agricultural credit market: Progress and performance of Kisan Credit Card. Indian Journal of Agricultural Economics, 66(3), 418-428.

Kumar, K. R., Kumar, K. K., \& Pant, G. B. (1994). Diurnal asymmetry of surface temperature trends over India. Geophysical Research Letters, 21(8), 677-680. https://doi.org/10.1029/94GL00007

Kumar, K. S. K., \& Parikh, J. (2001). Indian agriculture and climate sensitivity. Global Environmental Change, 11(2), 147-154. 
Kumar, S. N., \& Aggarwal, P. K. (2013). Climate change and coconut plantations in India: Impacts and potential adaptation gains. Agricultural Systems, $117,45-54$.

Kumar, S. N., Aggarwal, P. K., Rani, D. N. S., Saxena, R., Chauhan, N., \& Jain, S. (2014). Vulnerability of wheat production to climate change in India. Climate Research, 59(3), 173-187.

Kumar, S. N., Govindakrishnan, P. M., Swarooparani, D. N., Nitin, C., Surabhi, J., \& Aggarwal, P. K. (2015). Assessment of impact of climate change on potato and potential adaptation gains in the Indo-Gangetic Plains of India. International Journal of Plant Production, 9(1), 151-170.

Lindblade, K. A., Walker, E. D., Onapa, A. W., Katungu, J., \& Wilson, M. L. (2000). Land use change alters malaria transmission parameters by modifying temperature in a highland area of Uganda. Tropical Medicine \& International Health, 5(4), 263-274.

Lobell, D. B., \& Burke, M. B. (2010). On the use of statistical models to predict crop yield responses to climate change. Agricultural and Forest Meteorology, 150(11), 1443-1452. https://doi.org/10.1016/j.agrformet.2010.07.008

Lobell, D. B., Burke, M. B., Tebaldi, C., Mastrandrea, M. D., Falcon, W. P., \& Naylor, R. L. (2008). Prioritizing climate change adaptation needs for food security in 2030. Science, 319(5863), 607-610.

Luo, Z., Mu, R., \& Zhang, X. (2006). Famine and overweight in China. Review of Agricultural Economics, 28(3), 296-304.

Maccini, S., \& Yang, D. (2009). Under the weather: Health, schooling, and economic consequences of early-life rainfall. American Economic Review, 99(3), 1006-1026. https://doi.org/10.1257/aer.99.3.1006

Majra, J. P., \& Gur, A. (2009). Climate change and health: Why should India be concerned? Indian Journal of Occupational and Environmental Medicine, $13(1), 11$.

Mall, R. K., Singh, R., Gupta, A., Srinivasan, G., \& Rathore, L. S. (2006). Impact of climate change on Indian agriculture: A review. Climatic Change, 78(2), 445-478. https://doi.org/10.1007/s10584-005-9042-x

McMichael, A. J., Woodruff, R. E., \& Hales, S. (2006). Climate change and human health: Present and future risks. The Lancet, 367(9513), 859-869.

Misra, A. K. (2014). Climate change and challenges of water and food security. International Journal of Sustainable Built Environment, 3(1), 153-165. https://doi.org/10.1016/j.ijsbe.2014.04.006

MoEF. (2008). National Action Plan for Climate Change Report.

MoEF. (2010). India: Greenhouse Gas Emissions 2007 executive summary. Retrieved from http://www.moef.nic.in/downloads/public-information/ Report_INCCA.pdf

Müller, C., Elliott, J., \& Levermann, A. (2014). Food security: Fertilizing hidden hunger. Nature Climate Change, 4(7), 540. 
Myers, S. S., Smith, M. R., Guth, S., Golden, C. D., Vaitla, B., Mueller, N. D., ... Huybers, P. (2017). Climate change and global food systems: Potential impacts on food security and undernutrition. Annual Review of Public Health, 38(1), 259-277. https://doi.org/10.1146/annurev-publhealth-031816-044356

Myers, S. S., Zanobetti, A., Kloog, I., Huybers, P., Leakey, A. D. B., Bloom, A. J., ... Usui, Y. (2014). Increasing $\mathrm{CO}_{2}$ threatens human nutrition. Nature, $510(7503), 139-142$.

Nelson, G. C., Mensbrugghe, D., Ahammad, H., Blanc, E., Calvin, K., Hasegawa, T., ... Lotze-Campen, H. (2014a). Agriculture and climate change in global scenarios: Why don't the models agree. Agricultural Economics, 45(1), 85-101.

O’Brien, K., Leichenko, R., Kelkar, U., Venema, H., Aandahl, G., Tompkins, H., ... West, J. (2004). Mapping vulnerability to multiple stressors: Climate change and globalization in India. Global Environmental Change, 14(4), 303-313. https://doi.org/10.1016/j.gloenvcha.2004.01.001

Paaijmans, K. P., Blanford, S., Bell, A. S., Blanford, J. I., Read, A. F., \& Thomas, M. B. (2010). Influence of climate on malaria transmission depends on daily temperature variation. Proceedings of the National Academy of Sciences, 107(34), 15135-15139.

Paerl, H. W., \& Paul, V. J. (2012). Climate change: Links to global expansion of harmful cyanobacteria. Water Research, 46(5), 1349-1363. https://doi. org/10.1016/j.watres.2011.08.002

Patz, J. A., Campbell-Lendrum, D., Holloway, T., \& Foley, J. A. (2005). Impact of regional climate change on human health. Nature, 438(7066), 310.

Pettengell, C. (2010). Climate change adaptation: Enabling people living in poverty to adapt. Oxfam Policy and Practice: Climate Change and Resilience, 6(2), 1-48.

Pindyck, R. S. (2013). Climate change policy: What do the models tell us? Journal of Economic Literature, 51(3), 860-872.

Pindyck, R. S., \& Wang, N. (2013). The economic and policy consequences of catastrophes. American Economic Journal: Economic Policy, 5(4), 306-339.

Pingali, P. (2012). Green revolution: Impacts, limits, and the path ahead. Proceedings of the National Academy of Science, 109(31), 12302-12308. https://doi.org/10.1073/pnas.0912953109

Pingali, P. (2015). Wringing food from the world. Nature Geoscience, 8(4), 252-252. https://doi.org/10.1038/ngeo2410

Pingali, P. L., Spielman, D., \& Zaidi, F. (2014). Changing donor trends in assistance to agricultural research and development in Africa South of the Sahara. The Future of African Agricultural RéD, 6:1-6:25. https://doi.org/ 10.2499/9780896292123_06

Qadir, M., Tubeileh, A., Akhtar, J., Larbi, A., Minhas, P. S., \& Khan, M. A. (2008). Productivity enhancement of salt-affected environments through crop diversification. Land Degradation \& Development, 19(4), 429-453. https:// doi.org/10.1002/1dr.853 
Rasmussen, K. M. (2001). Is there a causal relationship between iron deficiency or iron-deficiency anemia and weight at birth, length of gestation and perinatal mortality? The Journal of Nutrition, 131(2), 590S-603S.

Ray, B. (2011). Climate change: IPCC, water crisis, and policy riddles with reference to India and her surroundings. Lexington Books.

Roseboom, T., de Rooij, S., \& Painter, R. (2006). The Dutch famine and its longterm consequences for adult health. Early Human Development, 82(8), 485-491.

Roseboom, T. J., Van Der Meulen, J. H. P., Ravelli, A. C. J., Osmond, C., Barker, D. J. P., \& Bleker, O. P. (2001). Effects of prenatal exposure to the Dutch famine on adult disease in later life: An overview. Molecular and Cellular Endocrinology, 185(1-2), 93-98.

Schuur, E. A. G., McGuire, A. D., Schädel, C., Grosse, G., Harden, J. W., Hayes, D. J., ... Lawrence, D. M. (2015). Climate change and the permafrost carbon feedback. Nature, 520(7546), 171-179.

Shah, M., \& Steinberg, B. (2012). Could droughts improve human capital? Evidence from India. Retrieved from http://www.frbsf.org/economicresearch/files/Shah_Steinberg.pdf

Sharma, A., \& Pingali, P. (2016). Does the onset of the rainy season affect crop yields in India? Ithaca, NY: Tata-Cornell Institute for Agriculture \& Nutrition.

Sharma, A., \& Pingali, P. (2018). Looking beyond rice \& wheat: Climate change impacts on food systems and food security in India. World Food Policy Journal, 4(2).

Shrestha, U. B., Gautam, S., \& Bawa, K. S. (2012). Widespread climate change in the Himalayas and associated changes in local ecosystems. PLoS One, $7(5), \mathrm{e} 36741$.

Singh, P., Nedumaran, S., Ntare, B. R., Boote, K. J., Singh, N. P., Srinivas, K., \& Bantilan, M. C. S. (2014). Potential benefits of drought and heat tolerance in groundnut for adaptation to climate change in India and West Africa. Mitigation and Adaptation Strategies for Global Change, 19(5), 509-529.

Sinha, S. K., \& Swaminathan, M. S. (1992). Deforestation, climate change and sustainable nutrition security: A case study of India. In N. Myers (Ed.), Tropical forests and climate (pp. 201-209). Dordrecht: Springer Netherlands. https:// doi.org/10.1007/978-94-017-3608-4_20

Skoufias, E., Rabassa, M., \& Olivieri, S. (2011). The poverty impacts of climate change: A review of the evidence.

Smit, B., Burton, I., Klein, R. J. T., \& Wandel, J. (2000). An anatomy of adaptation to climate change and variability. In Climatic change (Vol. 45, pp. 223-251). Springer. https://doi.org/10.1023/A:1005661622966

Smit, B., \& Wandel, J. (2006). Adaptation, adaptive capacity and vulnerability. Global Environmental Change, 16(3), 282-292.

Somanathan, E., Prabhakar, R., \& Mehta, B. S. (2009). Decentralization for costeffective conservation. Proceedings of the National Academy of Sciences, 106(11), 4143-4147.

Somanathan, E., \& Somanathan, R. (2009). Climate change: Challenges facing India's poor. Economic and Political Weekly, 44(31), 51-58. 
Somanathan, E., Somanathan, R., Sudarshan, A., \& Tewari, M. (2015). The impact of temperature on productivity and labor supply: Evidence from Indian manufacturing. Working Paper.

Soora, N. K., Aggarwal, P. K., Saxena, R., Rani, S., Jain, S., \& Chauhan, N. (2013). An assessment of regional vulnerability of rice to climate change in India. Climatic Change, 118(3-4), 683-699.

Speers, A. E., Besedin, E. Y., Palardy, J. E., \& Moore, C. (2016). Impacts of climate change and ocean acidification on coral reef fisheries: An integrated ecological-economic model. Ecological Economics, 128, 33-43. https://doi. org/10.1016/j.ecolecon.2016.04.012

Srivastava, A., Kumar, S. N., \& Aggarwal, P. K. (2010). Assessment on vulnerability of sorghum to climate change in India. Agriculture, Ecosystems of Environment, 138(3-4), 160-169.

Steiner, J. L., Briske, D. D., Brown, D. P., \& Rottler, C. M. (2018). Vulnerability of Southern Plains agriculture to climate change. Climatic Change, 146(1-2), 201-218.

Sutherst, R. W. (2004). Global change and human vulnerability to vector-borne diseases. Clinical Microbiology Reviews, 17(1), 136-173.

Swinnen, J., \& Squicciarini, P. (2012). Mixed messages on prices and food security. Science, 335(6067), 405-406. https://doi.org/10.1126/science.1210806

Tanser, F. C., Sharp, B., \& le Sueur, D. (2003). Potential effect of climate change on malaria transmission in Africa. The Lancet, 362(9398), 1792-1798. https:// doi.org/10.1016/S0140-6736(03)14898-2

Taylor, R. G., Scanlon, B., Döll, P., Rodell, M., Van Beek, R., Wada, Y., ... Edmunds, M. (2013). Ground water and climate change. Nature Climate Change, 3(4), 322.

Timmer, C. P. (1989). Food price policy. Food Policy, 14(1), 17-27. https://doi. org/10.1016/0306-9192(89)90023-7

Townsend, R. M. (1994). Risk and insurance in village India. Econometrica, $62(3), 539-591$.

Vedwan, N., \& Rhoades, R. E. (2001). Climate change in the Western Himalayas of India. Climate Research, 19(2), 109-117. Retrieved from http://www.jstor. org/stable/24866773

Vermeulen, S. J., Aggarwal, P. K., Ainslie, A., Angelone, C., Campbell, B. M., Challinor, A. J., ... Kristjanson, P. (2012). Options for support to agriculture and food security under climate change. Environmental Science \& Policy, 15(1), 136-144.

Verwimp, P. (2012). Undernutrition, subsequent risk of mortality and civil war in Burundi. Economics and Human Biology, 10(3), 221-231. https://doi. org/10.1016/j.ehb.2011.09.007

Watanabe, T., Ives, J. D., \& Hammond, J. E. (1994). Rapid growth of a glacial lake in Khumbu Himal, Himalaya: Prospects for a catastrophic flood. Mountain Research and Development, 14(4), 329-340. 
Watts, N., Adger, W. N., Agnolucci, P., Blackstock, J., Byass, P., Cai, W., ... Cooper, A. (2015). Health and climate change: Policy responses to protect public health. The Lancet, 386(10006), 1861-1914.

Weitzman, M. L. (2014). Fat tails and the social cost of carbon. American Economic Review, 104(5), 544-546.

Wigand, C., Ardito, T., Chaffee, C., Ferguson, W., Paton, S., Raposa, K., ... Watson, E. (2017). A climate change adaptation strategy for management of coastal marsh systems. Estuaries and Coasts, 40(3), 682-693.

Wodon, Q., \& Zaman, H. (2010). Higher food prices in Sub-Saharan Africa: Poverty impact and policy responses. The World Bank Research Observer, 25(1), 157-176. https://doi.org/10.1093/wbro/lkp018

Xiang, J., Bi, P., Pisaniello, D., \& Hansen, A. (2014). Health impacts of workplace heat exposure: An epidemiological review. Industrial Health, 52(2), 91-101.

Yip, R. (2000). Significance of an abnormally low or high hemoglobin concentration during pregnancy: Special consideration of iron nutrition. The American Journal of Clinical Nutrition, 72(1), 272S-279S.

Ziska, L. H., Gebhard, D. E., Frenz, D. A., Faulkner, S., Singer, B. D., \& Straka, J. G. (2003). Cities as harbingers of climate change: Common ragweed, urbanization, and public health. Journal of Allergy and Clinical Immunology, $111(2), 290-295$.

Open Access This chapter is licensed under the terms of the Creative Commons Attribution 4.0 International License (http://creativecommons.org/licenses/ by $/ 4.0 /$ ), which permits use, sharing, adaptation, distribution and reproduction in any medium or format, as long as you give appropriate credit to the original author(s) and the source, provide a link to the Creative Commons licence and indicate if changes were made.

The images or other third party material in this chapter are included in the chapter's Creative Commons licence, unless indicated otherwise in a credit line to the material. If material is not included in the chapter's Creative Commons licence and your intended use is not permitted by statutory regulation or exceeds the permitted use, you will need to obtain permission directly from the copyright holder.

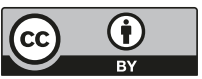

